\title{
Renal tubular acidosis and nerve deafness
}

\author{
D B DUNGER, D P BRENTON, AND A R CAIN \\ Royal United Hospital, Bath, and University College Hospital, London
}

SUMMARY Two brothers are described with renal tubular acidosis and nerve deafness: the elder also had rickets and hypokalaemia. The parents were unaffected. Studies of urinary acidification and bicarbonate excretion were consistent with a distal tubular abnormality. This report strengthens the view previously proposed in similar cases that nerve deafness and renal tubular acidosis constitute a genetic entity. Examination for nerve deafness is indicated in any child with renal tubular acidosis.

Renal tubular acidosis (RTA) is a syndrome of disordered tubular function, characterised by a sustained metabolic acidosis with hyperchloraemia, and an inappropriately high urinary $\mathrm{pH}$. Classical RTA (type 1) is a distal tubular defect with impaired hydrogen ion secretion. Bicarbonate excretion is generally only a small fraction of filtered bicarbonate $(<5 \%)$, but rather greater amounts of bicarbonate (6-9\% of filtered bicarbonate) are excreted by some children and this may be a distinct subgroup. ${ }^{1}$ Type 2 renal tubular acidosis is characterised by defective bicarbonate reabsorption in the proximal tubule. The renal tubular abnormality may be an isolated defect of bicarbonate reabsorption ${ }^{2}$ or there may be other abnormalities of tubular function, as in Fanconi's tubular disorders.

Classical (type 1) RTA is most commonly a sporadic condition and it is known to occur in association with a variety of disorders including hyperglobulinaemic states and some other inherited conditions-for example, Ehlers-Danlos syndrome, ${ }^{3}$ hereditary elliptocytosis, ${ }^{4}$ and osteopetrosis. ${ }^{5}$ Some of these other genetic associations may be fortuitous as classical (type 1) RTA may itself be a familial condition with a dominant inheritance. A syndrome of distal renal tubular acidosis with nerve deafness was first described by Royer and Broyer ${ }^{6} 10$ years ago in 3 unrelated patients. Other sporadic patients have been described ${ }^{7}$ but there is evidence that the condition is inherited as an autosomal recessive condition. Cohen et al. ${ }^{8}$ described two sibships

\footnotetext{
Institute of Child Health, London

D B DUNGER, research fellow

Department of Human Metabolism, University College Hospital Medical School, London

D P BRENTON, senior lecturer

Royal United Hospital, Bath

A R CAIN, consultant paediatrician
}

each with parental consanguinity, both sibships coming from a single large kinship. Konigsmark ${ }^{9}$ also found the condition in siblings and altogether there have been descriptions of 14 cases.

This paper describes two brothers with the syndrome of RTA and nerve deafness and the data obtained from them support the findings of Donckerwolcke et al. ${ }^{10}$ that the renal abnormality is confined to the distal tubule.

\section{Case reports}

The family pedigree is shown in Fig. 1. Plasma bicarbonate levels of the parents and siblings were normal. Early morning urine specimens showed normal acidification. Their hearing tests were also normal and nephrocalcinosis was not found on plain $x$-rays. The pedigree could not be investigated further as the grandparents still live in Jamaica.

Case 1 (born October 1969). The second child of West Indian parents with a normal birth history and a birthweight of $3 \cdot 2 \mathrm{~kg}$. He first presented at age 20 months with a history of anorexia, constipation, and

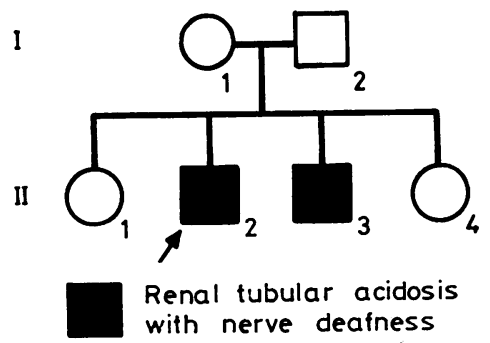

Fig. 1 Pedigree of affected siblings (Cases 1 and 2). 
delayed motor development. He was unable to walk because of severe rickets. Polydipsia was also noted at the time, but his blood chemistry was unremarkable, except that the plasma $\mathrm{Cl}$ was $113 \mathrm{mmol} / \mathrm{l}$ and $\mathrm{HCO}_{3} 16 \mathrm{mmol} / \mathrm{l}$. The rickets proved resistant to treatment with vitamin $\mathrm{D}$ but there was some doubt about how much treatment he received at home.

He was readmitted at age 3 years weighing $9 \cdot 1 \mathrm{~kg}$ with a height of $81.5 \mathrm{~cm}$. His condition had been deteriorating with respect to energy and appetite. The rickets was still active (Fig. 2a) and there was $x$-ray evidence of nephrocalcinosis. Biochemical results were as follows: plasma $\mathrm{Ca} 2 \cdot 15 \mathrm{mmol} / 1$
$(8.6 \mathrm{mg} / 100 \mathrm{ml})$, P $0.9 \mathrm{mmol} / 1(2.8 \mathrm{mg} / 100 \mathrm{ml})$, alkaline phosphatase $44 \mathrm{KA}$ units $/ 100 \mathrm{ml}$, Na 138 $\mathrm{mmol} / \mathrm{l}, \mathrm{K} 2 \cdot 2 \mathrm{mmol} / \mathrm{l}, \mathrm{Cl} 114 \mathrm{mmol} / \mathrm{l}, \mathrm{HCO}_{s} 14$ $\mathrm{mmol} / \mathrm{l}$, and urea $5.3 \mathrm{mmol} / 1(31.9 \mathrm{mg} / 100 \mathrm{ml})$, arterial pH $7 \cdot 34$, base excess $-13 \cdot 5 \mathrm{mmol} / 1$. Plasma creatinine normal. Urinary amino-acids normal. No glycosuria. A diagnosis of RTA was made and treatment started with sodium bicarbonate orally, $1 \mathrm{~g}$ three times a day being the initial maintenance dose. On this treatment alone he improved clinically and $x$-rays showed his rickets to be healed in May 1974 (Fig. 2b), his alkaline phosphatase having fallen to $23 \mathrm{KA}$ units $/ 100 \mathrm{ml}$.

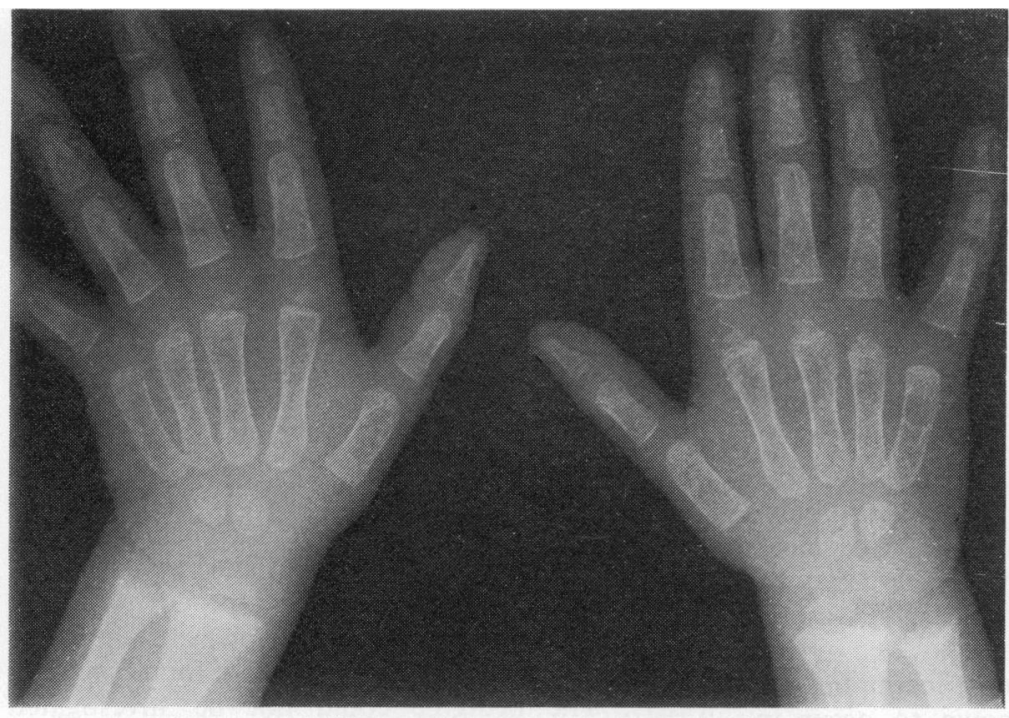

Fig. 2 Case 1. (a) Active rickets in October 1972.

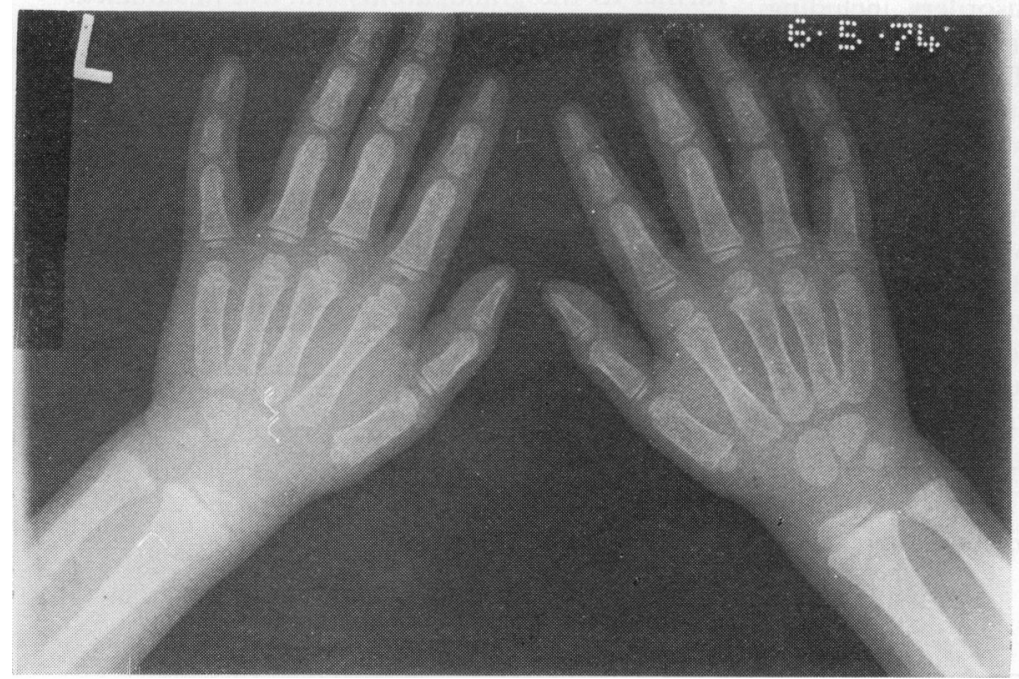

(b) Healed rickets in May 1974. 
At a further admission for investigation of the renal pathophysiology at age 7 years his height was $1.13 \mathrm{~m}$ (3rd to 10th centile) and weight $22.5 \mathrm{~kg}$ (on the 50th centile). The acidosis was controlled with $\mathrm{NaHCO}_{3}$, $1 \mathrm{~g}$ each day $(2 \cdot 13 \mathrm{mmol} / \mathrm{kg})$. Nephrocalcinosis was still present, but not increased. His growth curve showing catch-up growth is illustrated in Fig. 3. His rickets had remained healed.

Speech development was retarded at the first admission. Nerve deafness was demonstrated at age 4 years and hearing aids prescribed (Fig. 4).

Case 2 (born January 1974). The third child in the sibship and the brother of Case 1 . He was born after a normal pregnancy and delivery with a birthweight of $2.92 \mathrm{~kg}$. At age 3 months he presented with vomiting, weight loss, constipation, and polyuria. There was no $x$-ray evidence of rickets or nephrocalcinosis. Plasma urea $10 \mathrm{mmol} / \mathrm{l}(60 \cdot 2 \mathrm{mg} / 100 \mathrm{ml})$, $\mathrm{Na} 143 \mathrm{mmol} / \mathrm{l}, \mathrm{K} 3.7 \mathrm{mmol} / \mathrm{l}, \mathrm{Cl} 113 \mathrm{mmol} / \mathrm{l}$, $\mathrm{HCO}_{3} 13 \mathrm{mmol} / \mathrm{l}$, Ca $2 \cdot 54 \mathrm{mmol} / 1(10 \mathrm{mg} / 100 \mathrm{ml})$, P $2.0 \mathrm{mmol} / \mathrm{l}(6.19 \mathrm{mg} / 100 \mathrm{ml})$, alkaline phosphatase $21 \mathrm{KA}$ units $/ 100 \mathrm{ml}$. Urinary amino-acids normal. No glycosuria. A diagnosis of RTA was made and treatment started with sodium bicarbonate, the eventual maintenance dose being $1 \mathrm{~g}$ three times a day.

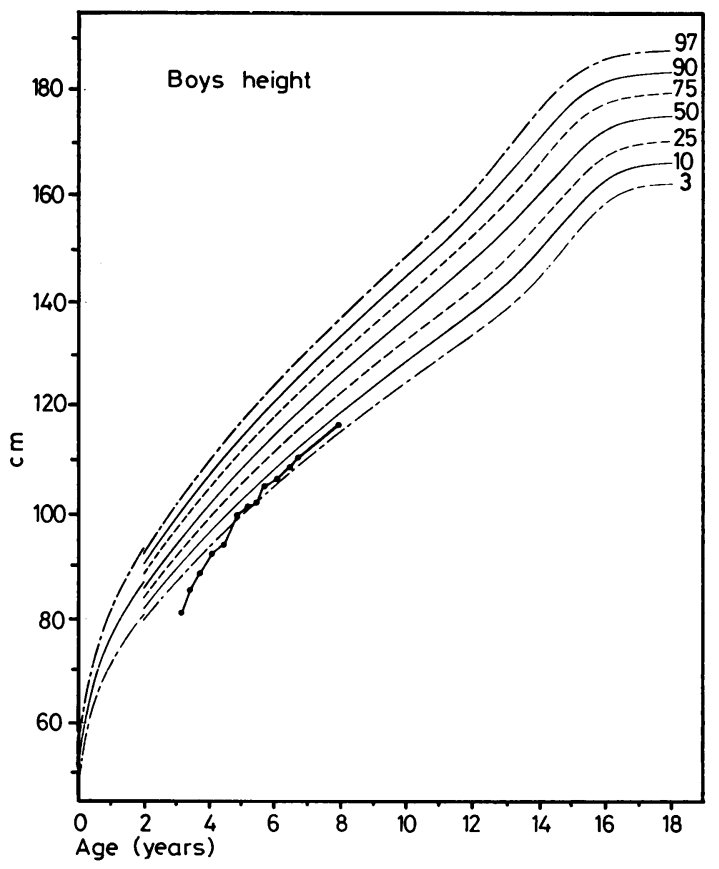

Fig. 3 Case 1. Catch up growth after the control of acidosis with sodium bicarbonate.

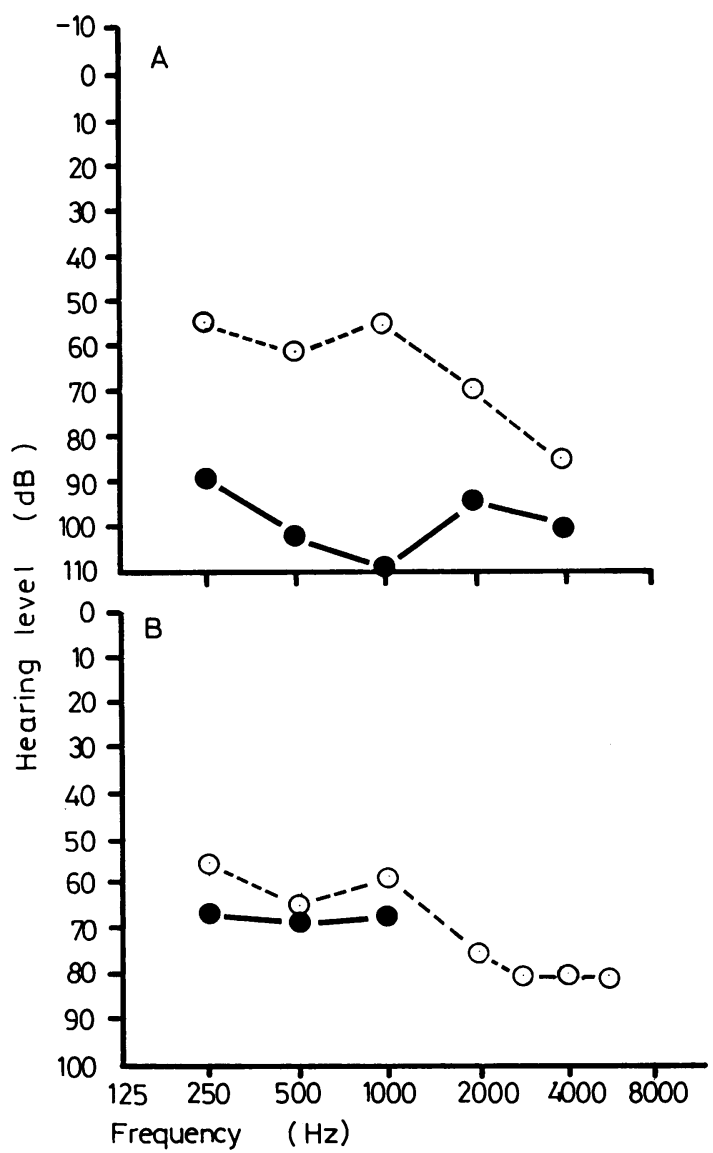

Fig. 4 Audiometry, (a) Case 1 at age $7 \cdot 3$ years, (b) Case 2 at age 3.7 years. Open circles, right ear; closed circles, left ear.

He was admitted again at age 2.9 years when his height was $88 \mathrm{~cm}$ and weight $12 \cdot 150 \mathrm{~kg}$. The acidosis was well controlled with $1 \mathrm{~g} \mathrm{NaHCO}_{3}$ three times a day. Nerve deafness had been suspected from an early age, and was confirmed by audiometry (Fig. 4). Hearing aids were prescribed.

\section{Results}

Renal investigations. The brothers were admitted to hospital for 7 days and oral bicarbonate was omitted for that period.

Glomerular filtration rate (GFR). This was estimated by creatinine clearance in both patients. Case 1: creatinine clearance, $99 \mathrm{ml} / \mathrm{min}$ per $1.73 \mathrm{~m}^{2}$. Case 2 : creatinine clearance, $64 \mathrm{ml} / \mathrm{min}$ per $1.73 \mathrm{~m}^{2}$. 
Maximum concentrating ability. This was assessed after a period of water deprivation and was found to be reduced in both patients. Maximum urinary osmolality in Case 1 was $560 \mathrm{mmol} / \mathrm{kg}$ water, and in Case 2 it was $580 \mathrm{mmol} / \mathrm{kg}$ water.

Urinary excretion of calcium and tubular reabsorption of phosphate. Urinary excretion of calcium was 0.07 $\mathrm{mmol} / \mathrm{kg}(2.8 \mathrm{mg} / \mathrm{kg})$ per 24 hours in Case 1 , and

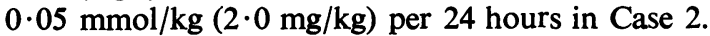
Renal tubular phosphate reabsorption was $91 \%$ normal in Case 1 and $95 \%$ normal in Case 2.

Urinary acidification. During spontaneous acidosis, urinary $\mathrm{pH}$ was matched against capillary Astrup estimations. High urinary $\mathrm{pH}$ values were observed right down to plasma $\mathrm{HCO}_{3}$ values of $10 \mathrm{mmol} / 1$ (Fig. 5).

Ammonium chloride loads $\left(100 \mathrm{mmol} / \mathrm{m}^{2}\right)$ were given as described by Edelmann et al. ${ }^{11}$ Comparison with normal data (Table) shows a high urine $\mathrm{pH}$ and an impaired excretion of $\mathrm{NH}_{4}{ }^{+}$and titratable acidity in both cases.

Bicarbonate reabsorption and excretion. Sodium bicarbonate $8.4 \%$ was given by continuous infusion

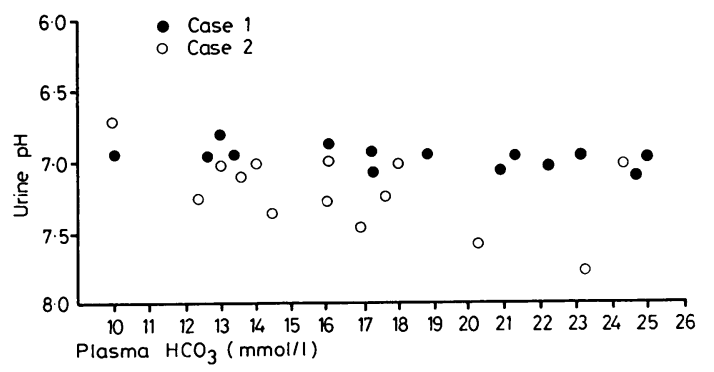

Fig. 5 Urinary $\mathrm{pH}$ values and plasma bicarbonate concentrations in Cases 1 and 2 after stopping treatment with sodium bicarbonate.

Table Data on plasma and urine 3 to 5 hours after oral ammoniun chloride $\left(100 \mathrm{mmol} / \mathrm{m}^{2}\right)$

\begin{tabular}{|c|c|c|c|c|c|c|}
\hline & \multicolumn{2}{|c|}{ Plasma } & \multicolumn{4}{|c|}{ Urine } \\
\hline & $p H$ & $\begin{array}{l}\text { Base } \\
\text { excess } \\
(\text { mmol/l) }\end{array}$ & $p H$ & $\begin{array}{l}T A \\
\text { ( } \mu \text { moll } \\
\text { min per } \\
\left.1.73 \mathrm{~m}^{2}\right)\end{array}$ & $\begin{array}{l}\mathrm{NH}_{4}^{+} \\
(\mu \mathrm{mol} / \\
\text { min per } \\
\left.1.73 \mathrm{~m}^{2}\right)\end{array}$ & $\begin{array}{l}\mathrm{NH}_{4}^{+} \\
(\mu \mathrm{moll} \\
100 \mathrm{ml} \\
\text { glomerular } \\
\text { flltrate })\end{array}$ \\
\hline $\begin{array}{l}\text { Case } 1 \\
\text { Case } 2 \\
\text { *Controls }\end{array}$ & $\begin{array}{l}7 \cdot 27 \\
7 \cdot 15 \\
7 \cdot 29\end{array}$ & $\begin{array}{l}-11 \cdot 1 \\
-16 \cdot 6 \\
-9 \cdot 1\end{array}$ & $\begin{array}{l}6 \cdot 81 \\
7 \cdot 11 \\
4 \cdot 87\end{array}$ & $\begin{array}{l}10 \cdot 1 \\
7 \cdot 5 \\
50 \\
(\mathrm{SE}= \\
3 \cdot 1)\end{array}$ & $\begin{array}{l}27 \cdot 96 \\
37 \cdot 6 \\
80 \\
(\mathrm{SE}= \\
3 \cdot 7)\end{array}$ & $\begin{array}{l}24 \cdot 95 \\
23 \cdot 1 \\
65 \\
(\mathrm{SE}= \\
5 \cdot 7)\end{array}$ \\
\hline
\end{tabular}

*Data on normal subjects from Edelmann et al.11

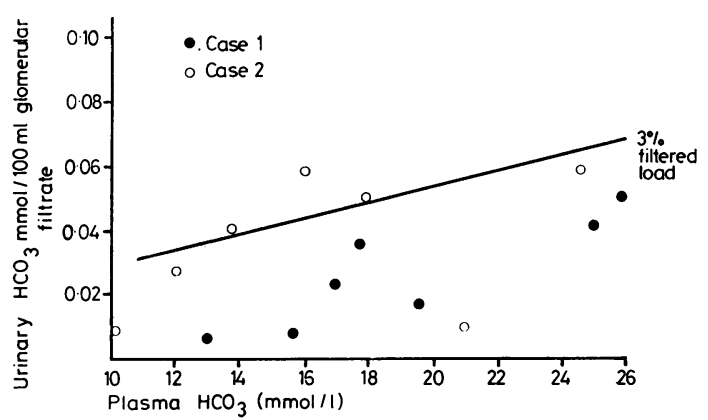

Fig. 6 Urinary bicarbonate excretion in Cases 1 and 2 in relation to plasma bicarbonate.

calculated to give a rise of $2 \mathrm{mmol} / \mathrm{l}$ per hour until normal plasma bicarbonate levels were reached. ${ }^{11}$ Bicarbonate was present in the urine of Case 1 at plasma bicarbonate concentrations between 13 and $26 \mathrm{mmol} / \mathrm{l}$, and in the urine of Case 2 at plasma bicarbonate concentrations between 10 and 24 $\mathrm{mmol} / \mathrm{l}$.

Bicarbonate excretion was always $3 \%$ or less of the filtered bicarbonate (Fig. 6).

\section{Discussion}

Most cases of renal tubular acidosis to have been reported (type 1) were detected in adult life and were sporadic. Familial occurrences have been found and several pedigrees clearly show an autosomal dominant mode of transmission. ${ }^{12}$

The association of deafness with RTA (type 1) in children was first noted by Royer and Broyer. ${ }^{6}$ The family described here is the fourth recorded example of affected siblings and the first in the UK. The pedigrees of other reported families strongly suggest that the syndrome is inherited as an autosomal recessive trait. The pedigree shown in Fig. 1 is consistent with a recessive mode of inheritance, either sex-linked or autosomal. A dominant form of inheritance in which an abnormal gene is present in one parent without producing any clinical effect seems unlikely in view of the presentation of the disease and the consistent clinical findings in both brothers early in life. Nevertheless it is possible that one parent has an incomplete RTA $^{13}$ which may be revealed only after ammonium chloride loading.

The cause of the syndrome of nerve deafness with distal tubular acidosis is not known. Kaplan et al. ${ }^{14}$ were unable to relate it to quantitative changes in red cell carbonic anhydrase or to changes in the electrophoretic mobility of this enzyme in affected patients. An association with nerve deafness would seem to imply an abnormality in a metabolic step or event, 
common to both the renal tubular cells and the cells in the cochlea.

The data obtained from the two brothers suggest that the renal abnormality is confined to the distal tubule. Despite severe degrees of systemic acidosis, the $\mathrm{pH}$ of the urine remained inappropriately high and bicarbonaturia persisted (Figs 5 and 6). The excretion of bicarbonate was $<3 \%$ of the filtered bicarbonate at normal and subnormal plasma bicarbonate concentrations (Fig. 6). A combination of distal tubular acidosis and bicarbonate loss as described by Morris et al..$^{1}$ can be excluded. The low amounts of alkali $(2.13 \mathrm{mmol} / \mathrm{kg}$ in Case 1 and 2.9 $\mathrm{mmol} / \mathrm{kg}$ in Case 2) required to achieve sustained correction of the acidosis is consistent with a diagnosis of RTA type 1.

With regard to the other features, failure to concentrate the urine maximally and the hypokalaemia (Case 1), the patients reported here do not differ from others with distal RTA not associated with nerve deafness. Rickets is also a well recognised complication of distal RTA although the cause of the rickets is not clear. Osteomalacia is a well recognised complication of distal RTA presenting in adult life and also of ureterosigmoidostomy ${ }^{15}$ which too results in hyperchloraemic acidosis. In both the osteomalacia may be treatable with sodium bicarbonate alone $\mathrm{e}^{16-17}$ as was the rickets in Case 1 reported here. Perry et al. ${ }^{18}$ have recently described a case of severe osteomalacia in a patient after ureterosigmoidostomy in whom sodium bicarbonate alone did not heal the bone disease and in whom there was relative resistance to vitamin D2. The patient's bone disease responded well to $1 \alpha$-hydroxycholecalciferol in doses of $1-2 \mu \mathrm{g} / 24 \mathrm{~h}$, suggesting a defect in renal hydroxylation of 25-hydroxycholecalciferol contributing to the bone disease. It is possible therefore that type 1 RTA with hyperchloraemic acidosis is associated with impaired renal hydroxylation of vitamin $D$ which at least in some cases can be improved by correction of the acidosis with sodium bicarbonate. This speculation awaits confirmation by the appropriate plasma assays of 1,25 dihydroxcholecalciferol in affected patients.

We thank D C W Godwin, chief technician, Department of Clinical Biochemistry, Royal United Hospital, Bath, and the sister and staff of the children's ward of the Royal United Hospital, Bath. The late Professor C E Dent took much interest in these patients.

\section{References}

1 Morris R C, Jr, Sebastian A, McSherry E. Renal acidosis. Kidney Int 1972; 1 : 322-40.

2 Rodriguez-Soriano J. The renal regulation of acid base balance and the disturbance noted in renal tubular acidosis. Pediatr Clin North Am 1971; 18: 529-45.

3 Levine A S, Michael A F, Jr. Ehlers-Danlos syndrome with renal tubular acidosis and medullary sponge kidneys. J Pediatr 1967; 71: 107-13.

4 Baehner R L, Gilchrist G S, Anderson E J. Hereditary elliptocytosis and primary renal tubular acidosis in a single family. Am J Dis Child 1968; 115: 414-9.

5 Vainsel M, Fondu P, Cadranel S, Roemans C L, Gepts W. Osteopetrosis associated with proximal and distal tubular acidosis. Acta Paediatr Scand 1972; 61: 429-34.

- Royer P, Broyer M. L'acidose rénale au cours des tubulopathies congénitales. In proceedings of actualités néphrologiques de l'hôpital Necker. Paris: Flammarion, 1967: 73.

7 Nance W E, Sweeney A. Evidence for autosomal recessive inheritance of the syndrome of renal tubular acidosis with deafness. Birth Defects 1971; 7: No. 4, 70-3.

8 Cohen T, Brand-Avrahan A, Karshai C, et al. Familial infantile renal tubular acidosis and congenital nerve deafness: an autosomal recessive syndrome. Clin Genet 1973; 4: 275-8.

- Konigsmark B W. Renal tubular acidosis with progressive nerve deafness. Cited by McKusick in Mendelian inheritance in man. 2nd ed. Baltimore: Johns Hopkins Press, 1968: 357.

10 Donckerwolcke J R A, van Biervliet J P, Koorwaar G, Kuyten R, van Stekelenburg G J. The syndrome of renal tubular acidosis and nerve deafness. Acta Paediatr Scand 1976; 65: 100-4.

11 Edelmann C M, Jr, Soriano J R, Boichis H, Gruskin A B, Acosta M I. Renal bicarbonate reabsorption and hydrogen ion excretion in normal infants. $J$ Clin Invest 1967; 46: 1309-17.

12 Seldin D W, Wilson J D. Renal tubular acidosis. In: Stanbury J B, Wyngaarden J B, Fredrickson D S, eds. The metabolic basis of inherited disease. 4th ed. New York: McGraw Hill, 1978: 1618.

13 Wrong $O \mathrm{M}$, Davies $\mathrm{H}$ E F. The excretion of acid in renal disease. $Q J$ Med 1959; 28 : 259-313.

14 Kaplan B S, Mills M, Hechtman P, Leblanc D. Red blood cell carbonic anhydrase activity in children with distal renal tubular acidosis. Pediatr Res 1977; 11 : 1039-42.

15 Donohoe J F, Freaney R, Muldowney F P. Osteomalacia in uretero-sigmoidostomy. Ir J Med Sci 1969; Series 7, 2: $523-30$.

16 Foss G L, Perry C B, Wood F Y J. Renal tubular acidosis. $Q J$ Med 1956; 25: 185-200.

17 Tobler R, Prader A, Bühlmann A. Rachitis als Folge der Ureterosigmoidostomie. Helv Paediatr Acta 1957; 12: 215-40.

18 Perry W, Allen L N, Stamp T C B, Walker P G. Vitamin $\mathrm{D}$ resistance in osteomalacia after ureterosigmoidơstomy. N Engl J Med 1977; 297: 1110-2.

Correspondence to Dr D B Dunger, Institute of Child Health, 30 Guilford Street, London WC1N $1 \mathrm{EH}$.

Received 3 April 1979 